\title{
THE HIERARCHY AND TYPOLOGY OF FAMILY SOCIAL SUPPORT NETWORKS AND THEIR IMPLICATIONS FOR SOCIAL SERVICES
}

\author{
Ivana Loučková1, Alice Gojová
}

\begin{abstract}
This article examines the importance of family social support networks and their implications for social services. Social support networks are a significant factor in effective assistance to families. This research uses an integrated strategy and factor analysis to identify stakeholders of social support services and the extent in which these services are considered important by families in terms of solving their problems. Our findings show that assistance to families is expected in three levels. The first involves direct interpersonal relationships (between family members and friends) and when this level fails, the network of professionals and experts is the next provider. An effective network of support services to families "stands and falls" with active family relationships. Where family relationships are absent or dysfunctional, they are compensated by second and third levels of this support. In a developed network of support services, social workers should have tools available to support all three levels. In view of these findings, a trend emphasizing approaches in favor of families solving their own problems rather than professional dominance of such is worth investigating.
\end{abstract}

UDC Classification: 354, DOI: http://dx.doi.org/10.12955/cbup.v4.772

Keywords: social networks, family, social services.

\section{Introduction}

According to Beck (2007), the transition of society into the second era of modernity brings with it a commensurate loss of stability, a "breaking from the natural order," and the arrival of an "at-risk society," which is also reflected in the increasing fragility of the family, the aging of the general population, and a decline in solidarity within society (Keller, 2012).

According to other authors (Taylor-Gooby, 2004; Keller, 2012; Sirovátka \& Winkler, 2010), new social risks will significantly affect families, especially single parent families, which, due to family break-ups, involve children in custodial arrangements, or that which is often termed "patchwork" families, an example of recognizing pluralism in family life situations (Beck \& Beck-Gernsheim, 2004). However, entry into the era of the twenty-first century does not alter the fact that the roots of stability for the individual resonates in a family, and although there are currently diverse forms of partner coexistence and communities, there is no doubt that families, especially families with children, are the elementary unit of society.

The Czech Republic, as a member of the European Union, and as a state that respects fundamental human rights and freedoms, has committed to a high level of child and family protection. Therefore, the family unit must provide at least a basic level of care and development for children and bridge the gap between the child and society. Different services, including social services offered to families, ensure the minimization of risks to the family and its functionality. The development of such services is a response to the break-up of families, which is common, and the increase of individualization in society, but, paradoxically, it is also expected in times of crisis and with weakening of the welfare state.

The question is how to set up a system of social services that is not only feasible, but also effective at the time of a family crisis as well as during a crisis of the welfare state and increasing individualization of society.

\section{Family Social Support Network}

Social networks are "social arrangements of people, groups, organizations, or other social units that interact and engage in exchanges to achieve their purposes" (Hardcastle, Powers, \& Wenocur, 2004, p. 294). Family support networks are an important source of help in problematic situations and involve both informal and formal supportive persons and institutions.

\footnotetext{
${ }^{1}$ Ivana Loučková, Faculty of Social Studies, University of Ostrava, ivana.louckova@osu.cz

2 Alice Gojová, Faculty of Social Studies, University of Ostrava, alice.gojova@osu.cz
} 
Fuchs (in Rowe \& Rapp-Paglicci, 2008) distinguishes three types of bonds or relations within support networks. He defines these as the primary (family, relatives, and friends), secondary (neighbors, coworkers, and volunteers) and tertiary (organizations and social service providers). Some families have an over-representation in such formal networks (Collins, Jordan, \& Coleman, 2007).

A significant factor in effective assistance to families involves social support networks. McKeown (2000), in his study entitled "A Guide to What Works in Family Support Services for Vulnerable Families", found that it was not the methods or techniques used, but rather the social influences, such as the environment $(40 \%)$ or the relationship between client and social worker (40\%) that were crucial. The techniques in working with families had only a limited effect, whereas a client and other persons in his or her surroundings, including a social worker, contributed to problem solving in a significantly greater way, provided that the family chose the cooperation voluntarily. Following upon this logic, the parties the families expected to gain support from were considered an important aspect for further development of social services.

\section{Purpose of the Study and its Methodology}

This study aimed to identify stakeholders and the extent of social support services considered important in the solving of problems for families with children. We considered the findings that were essential in designing an effective network of social services for families with children, and in accepting the preferences of families in terms of their importance and nature.

Data were obtained during the research project, "System support of transformation processes of care system for vulnerable children and their families", which was conducted by an author of this paper on behalf of the research agency Sociotrendy. This research was carried out on behalf of the Ministry of Labor and Social Affairs, whose goal was to define a model of the minimum framework for a service network for vulnerable children and families in municipalities that had extended powers (Sociotrendy, 2015).

The research sample consisted of family members who had been rearing at least one child under the age of 26 years. An integrated research strategy with a predominance of quantitative methods (Loučková 2010) was used to identify the respondents' relation to the thematic areas, in particular, those associated with the service network, which in a disadvantaged social situation, would be part of their normal connections.

Individual citizens were asked a set of questions in structured interviews through an interviewer network. The research sample was compiled proportionately, based on demographic data, so as to include the relevant sample units for the two regions, the choice of which was intentional. In one region, most social services for vulnerable children and families within the Czech Republic were available, while in the other, relatively few social services existed. For the sample size of 624 respondents, the selective statistical error was $4.0 \%$. Source data of the research sample incorporated 624 entries and 91 indicators, from which the secondary quantitative data, serving as the groundwork for further analytical work, were derived. Verbal information was subjected to a content analysis.

The research sample for the evaluated regions was structured according to the number and proportion of respondents in municipalities with "extended powers". The statistical tests involved reduction of the data matrix containing encoded information through its characteristic values and vectors. Where no statistically significant differences were found between the regions in relation to the analyzed variables (i.e., thematic units), the research units of both regions were combined into one research sample and the analytical work oriented towards setting objectives using a total research sample. Given the choice of regions, the absence of statistical significance of variables with respect to the jurisdiction of the regions and an integrated research strategy with predominance of quantitative techniques, the research results were considered transferable to the wider public, under the above definition.

The researched issues were analyzed at two simultaneous levels. The first level was about finding the hierarchy of analyzed entries through appropriate indexes, which were set as the weighted average corresponding to the encoded answers of respondents. The second level was about finding typologies using a factor analysis. The factor analysis, as one of the most sophisticated multi-dimensional analyses, provided insight into all data analyzed, in terms of reciprocal relationships that corresponded to entries analyzed, as well as from an isolated view of individual dimensions (entries). The considered 
factors acted as psychological groupings of different attitudes of the interviewees, through the sought relations (i.e., through the calculated correlations), which, in each entry, were saturated by certain factors (called loadings). These factors, and their corresponding entries, were significant. Therefore, before initiating the analysis, a query specified whether factors existed in terms of the potentialities, by which action those entries were grouped and which way they were "similar" to each other through the influence of a given factor. The objective of the analysis was to identify the anticipated factors.

\section{Results}

\section{Model of Service Network for Families with Children}

The importance of assistance from a particular entity, that is, the stakeholders engaged in solving specific and difficult life situations, may not (but can) coincide with assistance provided in the past. The relevance of support is the respondents' choice, and in their view, the most appropriate methods were applied. It was about who (and what amount of intensity) should be provided in support addressing their life problems.

We assumed that there will be no change in the order of stakeholders involved in providing regular assistance. Although, help from some stakeholders was generally expected, such help was not necessarily needed for internalized relief, based on personal experience. Therefore, the importance of those stakeholders potentially offering assistance was analyzed, not only by the order of individual entries, or their hierarchies, but also by mutual relations in regard to the effect of latent factors. Although originally unmeasured, these factors were readily detectable from the numerical data, which depended on the responses of individual respondents. Subsequently, the factors were projected in groups of entries, based on their typology, or, in our case, the construction of the network.

\section{Stakeholders Involved in the Assistance to Families with Children: The Hierarchy of Assistance}

For the battery of questions specifying the individual stakeholders whose assistance was perceived as most important, a set of entries, as listed in Table 1, was used. The intensity of the required assistance, based on the respondents' view, was measured on a school grading scale of 1 to 5, where " 1 " meant maximum need for assistance and " 5 " no need for assistance from the stakeholder. From this, the index of importance of assistance was calculated. The smaller the size of an achieved index, the greater the need for adequate assistance from the particular entity was evident.

The hierarchy of stakeholders offering assistance, in order of importance, is listed in Table 1. For completeness, the table shows the number of respondents who commented on the particular entry and the maximum and minimum value of that entry, for different stakeholders. The maximum importance in the context of each entry, or the aid required by the stakeholder, was expressed as Grade 1, and the maximum insignificance as Grade 5. Therefore, in addition to the help from relatives, every stakeholder was perceived, at least once, as insignificant. Relatives had an average grading of importance (Grade 3).

Important and necessary assistance was expected from life partners and family (siblings and other relatives). Children were listed by the respondents in the latter order, as were friends.

\section{Typology of Assistance}

To identify a group typology of potential stakeholders or participants in assistance, a factor analysis was performed. This method considered the intensity of the required help in reciprocal relationships. Three factors, which offered three different levels of assistance, were extracted from the group of stakeholders who were potentially ready to help, i.e., the relevant entries

The importance of the need for assistance from social services, psychologists, and teachers came to the fore last. Assistance from members of interested groups and associations were the least expected.

The first factor (listed in Table 2) explained approximately a quarter (24\%) of the variability in the analyzed data, known as "the factor saturation". Stakeholders engaged in services grouped in this respect included siblings, relatives, spouses (partners), and friends, as well as children (sons and daughters). This involved a network of the closest associates. This factor was defined as "the internal relationship factor". 
Table 1: Index of the Importance of Assistance in a Problematic Life Situation

\begin{tabular}{|lllll|}
\hline Assistance required & $\begin{array}{c}\text { Number of } \\
\text { respondents }\end{array}$ & $\begin{array}{c}\text { Borderline } \\
\text { of the } \\
\text { maximum } \\
\text { required } \\
\text { assistance }\end{array}$ & $\begin{array}{c}\text { Borderline of } \\
\text { no assistance } \\
\text { required }\end{array}$ & $\begin{array}{c}\text { Index of the } \\
\text { importance } \\
\text { of assistance }\end{array}$ \\
By spouse (partner) & 554 & 1 & 5 & 1.09 \\
By relatives & 554 & 1 & 3 & 1.11 \\
By siblings & 554 & 1 & 5 & 1.12 \\
By children (sons and daughters) & 552 & 1 & 5 & 1.36 \\
By friends & 554 & 1 & 5 & 1.73 \\
By social service providers & 554 & 1 & 5 & 2.59 \\
By psychologist (family & & & & \\
counselling) & 550 & 1 & 5 & 2.68 \\
By teacher (school) & 552 & 1 & 5 & 2.76 \\
By employer & 552 & 1 & 5 & 2.85 \\
By local authority & 552 & 1 & 5 & 2.88 \\
By doctor & 550 & 1 & 5 & 2.91 \\
By police, court & 544 & 1 & 5 & 3.37 \\
From interest groups and from by & & & & \\
associations & 550 & 1 & 5 & 3.53 \\
\hline Source: Authors & & & & \\
\hline
\end{tabular}

The second factor (listed in Table 3) explained almost a quarter (22\%) of the variability in the analyzed data. The effect of this factor included the stakeholders who were providing assistance, such as the psychologists (family counselling), doctors, teachers (school), members of interest groups, and associations, as well as employers. This was a network of experts and professionals. It was defined as "the professional relationship factor".

The third factor (listed in Table 4) explained a fifth (20\%) of the variability in the analyzed data. The effect of this factor included the assistance provided by social services, local authority, police, or the courts, or a combination of these. This factor was defined as "the institutional relationship factor".

\begin{tabular}{|lc|}
\hline Table 2: Internal Relationship Factor & \\
\hline Entries of the factor with 24\% saturation (rotated solution) & Factor loading \\
By siblings & .940 \\
By relatives & .921 \\
By spouses (partners) & .857 \\
By friends & .537 \\
By children (sons and daughters) & .520 \\
\hline Source: Authors & \\
\hline
\end{tabular}

Table 3: Professional Relationship Factor

$\begin{array}{lc}\text { Entries of the factor with 22 \% saturation (rotated solution) } & \text { Factor loading } \\ \text { By psychologist (family counselling) } & .780 \\ \text { By employer } & .779 \\ \text { By teacher (school) } & .725 \\ \text { By doctor } & .682 \\ \text { By interest groups and associations } & .549\end{array}$

Source: Authors 
Table 4: Institutional Relationship Factor

Entries of the factor with $20 \%$ saturation (rotated solution)

By social service providers

Factor loading

By local authority

.901

By police, court

.885

.678

Source: Authors

An efficient network of social services should be based on natural relationships and the needs of those for whom it is designed. The above analyses show that families with children expect social services on three levels (listed in Figure 1). The first consists of direct interpersonal relationships, where the key relations are between family members, relatives, children, and friends. Where this first level of the network fails, a network of professionals and experts becomes the expected provider of social services. The key relations in this level are those of families, in particular, family members with psychologists, doctors, or teachers or a combination of these. When this level of network fails, help and services from an institutional network are expected. In this respect, the key relations are those of family members with employees of the relevant social service provider, such as staff at relevant local authorities, courts, and police departments.

\section{Conclusion}

The service network for families with children, and which should be effective in terms of its maximum usage, is expected at three levels. Although the final findings may seem predictable, they are based on research results, rather than previously stated speculations.

The main conclusions:

Figure 1: The Service Network for Families

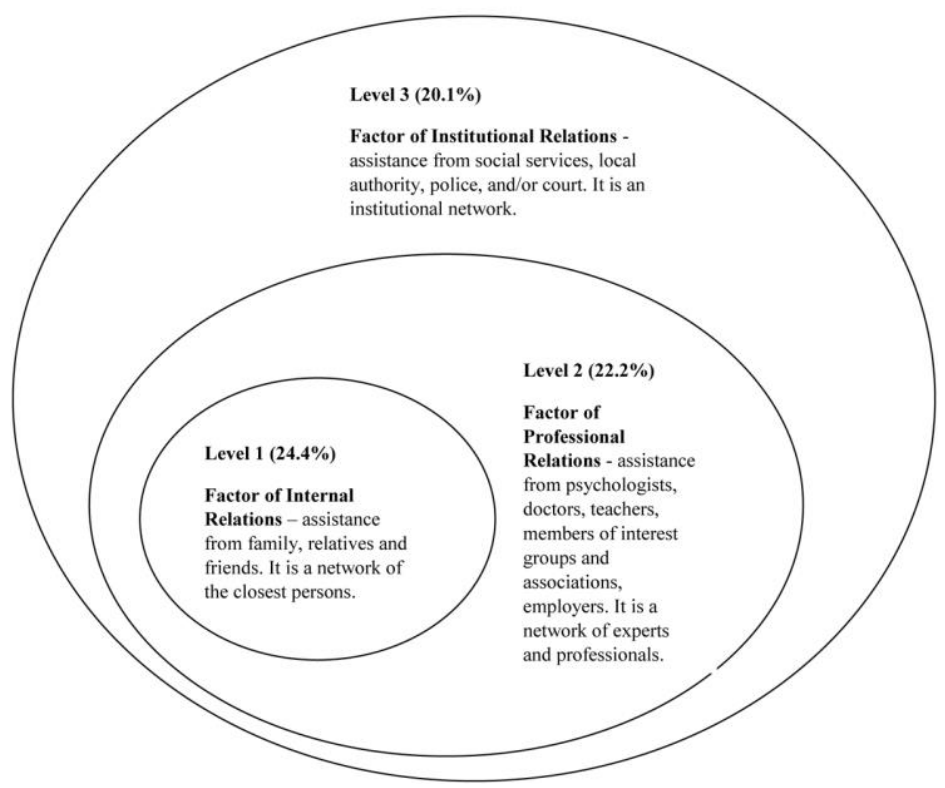

Source: Authors

- Effective development of a support network for families with children "stands or falls" with active family relations (also kinship and friendship). This is the first level of social support network. If the family relations are absent or dysfunctional, the second-level care providers take over.

- The second level of a support network should be based on the active relations between family members and schoolteachers, doctors, and staff members in children's after-school activity 
clubs or groups. If the family relations are absent or dysfunctional, the third-level care providers take over.

- The third level of the social support network is assistance to families using institutions (social service institutions, authorities, courts, and police).

- Where the development of the service network is based mainly on institutional integration, most likely the network will be used seldom and function unsatisfactorily. This does not in any way reduce the institutional integration of the support network in the case of exposure of a child to danger, otherwise it would be virtually impossible to help a child in a crisis or situation of absence or dysfunction of family relations using teachers and other professionals.

Where the network of social services is developed as part of social work, social workers should have tools to support three-levels of the service network. In current practice, tools to foster relationships within families and their close social environment (i.e., the level 1 and 2 relations) are especially lacking. Based on these findings, a closer look at the trend of approaches that criticize professional dominance and emphasize solving problems by the families themselves is recommended. These approaches include family group conferences (Clarijs \& Malmberg, 2012; Burford \& Hudson \& 2000). Research on the implementation of family group conferences showed that the key to success is investing in the social networking of families (Frost, Abram \& Burgess, 2014). To support the thirdlevel services we should have and use tools to promote relations between the recipients of services (children and their parents) and the institutions providing services (social service authorities, courts, and police). The third level is the one that is currently managed in the most transparent and bestquality manner.

Overall, it is concluded that anticipating the extent that family relations and kinship are important to the majority of the population was difficult. Demonstrating that an effective network of services for families should be focused on support for family relations does not inevitably argue that an institutionalized network involves a lower level of quality.

When using the methods of social work (e.g., case management and networking), social workers should focus mostly on levels 1 and 2 types of networks. Where there is family dysfunction or complete absence of family relationships (significant sources of danger for families) it is appropriate to support both traditional family relationships as well as alternate family units. The research results show that support for families and family relations is important and promotes transformational activities that have been implemented and are ongoing in the Czech Republic over several recent years.

\section{References}

Beck, U. (2007). Vynalézání politiky. K teorii reflexivní modernizace. [Inventing policy. The theory of reflexive modernization.] Praha: SLON

Beck, U., \& Beck-Gernsheim, E. (2004). Families in a Runaway World. Scott, J., Treas, J., Richard, M. The Blackwell Companion to the Sociology of Families. Oxford: Blackwell Publishing.

Burford, G., \& Hudson, J. (2000). Family Group Conferencing. New Directions in Community-Centered Child and Family Practise. New Jersey: Transaction publishers.

Clarijs, R., \& Malmberg, T. (2012). The Quiet Revolution, Aggrandising People Power by Family Group Conferences. Amsterdam: SWP Publishes.

Collins, S., Jordan, C., \& Coleman, H. (2007). An Introduction to Family Social Work. Belmont: Thomson Higher Education.

Frost, N., Abram, F., \& Burgess, H. (2014). Family group conferences: evidence, outcomes and future research. Child \& Family Social Work, 19 (4), 501-507.

Hardcastle, D. A., Powers, P. R., \& Wenocur, S. (2004). Community Practice. Theories and Skills for Social Workers. New York: Oxford University Press.

Keller, J. (2012). Nová sociální rizika a proč se jim nevyhneme. [New social risks and why not avoid them.] Praha: SLON.

Loučková, I. (2010). Integrovaný přístup v sociálně vědním výzkumu. Praha: Sociologické nakladatelství [An integrated approach to social science research. Prague : Sociological publishing] SLON.

McKeown, K. (2000). A Guide to what works in family support services for vulnerable families. Dublin. (3.1.2016) Retrieved from:

http://www.dcya.gov.ie/documents/publications/A_Guide_to_what_Works_in_Family_Support_Serviecs_for_Vunerable_F amilies.pdf 
Rowe, W., \& Rapp-Paglicci, L. A. (eds.) (2008). Comprehensive Handbook of Social Work and Social Welfare. New Yersay: Wiley.

Sirovátka, T., \& Winkler, J. (2010). Význam „,nových sociálních rizik“v současné společenské vědě. In: Sociální studia. Brno: Fakulta sociálních studií Masarykovy university [Meaning " new social risks " in contemporary social science. In Social Studies . Brno: Faculty of Social Studies], 2010, 1, 7-21.

Sociotrendy (2015). Model minimálního rámce sítě služeb na úrovni obcí s rozšířenou působností. [Model minimum framework network services at the level of municipalities with extended powers.] Praha: MPSV.

Taylor-Gooby, P. (2004). New Risks, New Welfare. The Transformation of the Welfare State. Oxford: Oxford University Press. 